Portland State University

PDXScholar

8-19-1977

\title{
Landscape Painting in the Secondary Classroom
}

Margaret Shirley

Portland State University

Follow this and additional works at: https://pdxscholar.library.pdx.edu/open_access_etds

Part of the Art and Design Commons, and the Art Education Commons Let us know how access to this document benefits you.

\section{Recommended Citation}

Shirley, Margaret, "Landscape Painting in the Secondary Classroom" (1977). Dissertations and Theses. Paper 2578.

https://doi.org/10.15760/etd.2575

This Thesis is brought to you for free and open access. It has been accepted for inclusion in Dissertations and Theses by an authorized administrator of PDXScholar. Please contact us if we can make this document more accessible: pdxscholar@pdx.edu. 
AN ABSTRACT OF THE THESIS OF Margaret Shirley for the Master of Science in Teaching presented August 19, 1977.

Title: Landscape Painting in the Secondary Classroom APPROVED BY MEMBERS OF THE THESIS COMMITTEE:
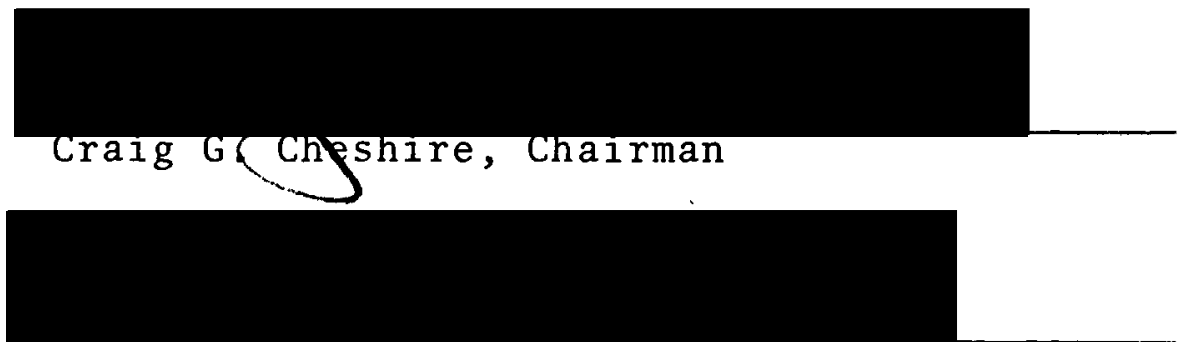

Byron J. Gardner

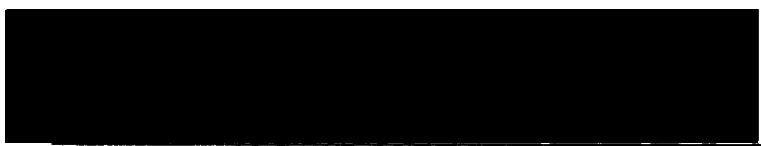

James Hibbard

This thesis attempts to demonstrate an approach to secondary art education which will emphasize the student's own experience as the basis of his art work. Furthermore, the students' learning activities are given a broader context by the inclusion of material from the history of art within the framework of the studio course. Such an integrated approach can give meaningful insight to the adolescent as he deals with experience in a visual form.

This orientation to art education has evolved through the writer's own teaching experience and from reading the works of art educators. In preparation for the thesis, I 
researched the history of landscape painting, current material on art education and adolescent psychology, and the formal, technical aspects of using color in art. The problem became that of integrating this diverse information into coherent teaching units.

Landscape painting is the subject of the teaching units, or chapters; and each chapter deals with a different approach to the world of nature. The thesis consists of five chapters, including an introduction and a summary. The central chapters contain two sections: one based on the history of art and the other on related student experiences and classroom procedures. A specific lesson plan is included at the end of each chapter. 
LANDSCAPE PAINTING IN THE SECONDARY CLASSROOM

$$
\text { by }
$$

\title{
MARGARET SHIRLEY
}

A thesis submitted in partial fulfillment of the requirements for the degree of

\author{
MASTER OF SCIENCE \\ in \\ TEACHING \\ in \\ ART
}


TO THE OFFICE OF GRADUATE STUDIES AND RESEARCH:

The members of the Committee approve the thesis of Margaret Shirley presented August 19, 1977.
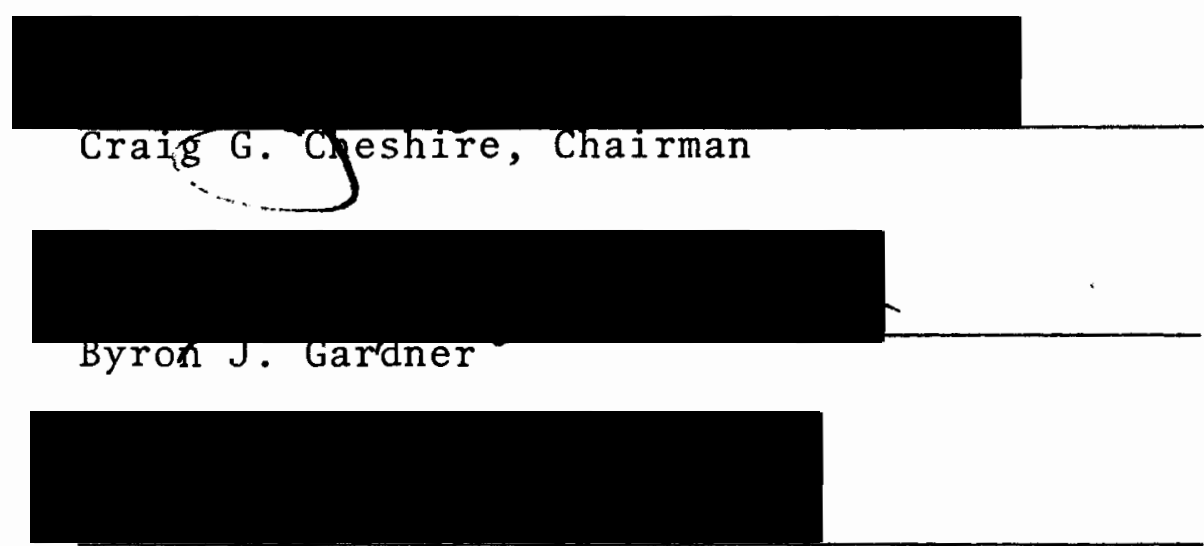

James Hibbard

APPROVED :

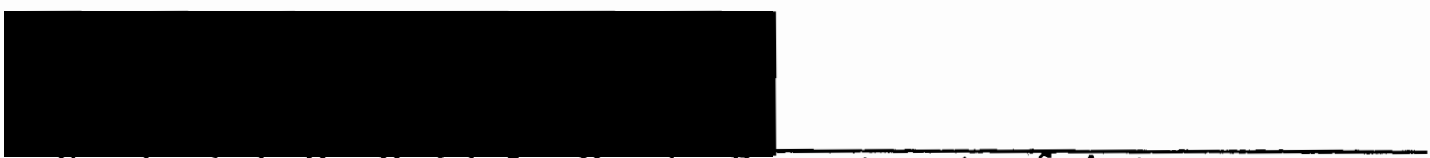

Frederlck H. Heldel, Head, Department of Art

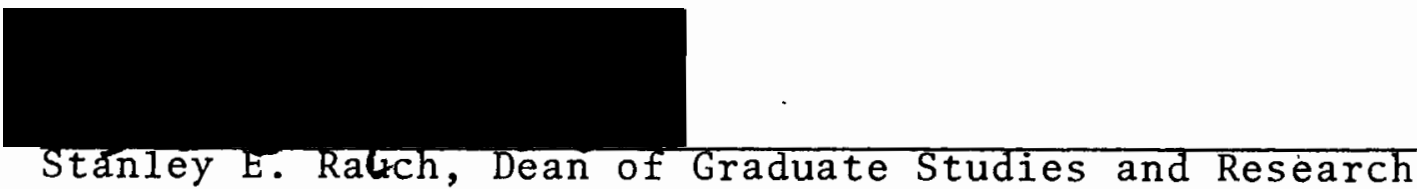


TABLE OF CONTENTS

Page

LIST OF FIGURES . . . . . . . . . . . . . . . . iv CHAPTER

I INTRODUCTION . . . . . . . . . . . . . . . . I I

I I THE LANDSCAPE AS KNOWLEDGE . . . . . . . . 5

History of Art: The Renaissance,

Leonardo da Vinci. . . . . . . . . . 5

Classroom Procedures and Student

Experiences . . . . . . . . . . . . . 11

Lesson Plan . . . . . . . . . . . 14

II THE LANDSCAPE AS FEELING . . . . . . . . . . 17

History of Art: The Nineteenth Century,

Vincent van Gogh ........... 17

Classroom Procedures and Student

Experiences............. 22

Lesson Plan . . . . . . . . . . . 24

IV THE LANDSCAPE AS CONCEPT . . . . . . . . 26

History of Art: The Twentieth Century,

Wassily Kandinsky........... 26

Classroom Procedures and Student

Experiences . . . . . . . . . . 32

Lesson Plan . . . . . . . . . . 34

V SUMMARY . . . . . . . . . . . . . . . 37

FOOTNOTES . . . . . . . . . . . . . . . . . 39

SOURCES CONSULTED ........................ 42 


\section{LIST OF FIGURES}

FIGURE

PAGE

1 Leonardo da Vinci. The Valley of the Arno . . 7

2 Leonardo da Vinci. Lily . . . . . . . 8

3 Leonardo da Vinci. Study of a plant . . . . . 8

4 Leonardo da Vinci. Study of Rocks . . . . . . . 9

5 Leonardo da Vinci. Madonna of the Rocks . . . 10

6 Leonardo da Vinci. Madonna of the Rocks

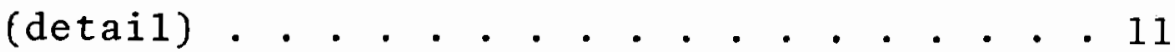

7 Leonardo da Vinci. Madonna of the Rocks (detail).............. 11

8 Vincent van Gogh. Le Pont de Langlois . . . . 20

9 Vincent van Gogh. The Park of the Asylum . . 20

10 Vincent van Gogh. The Starry Night . . . . 22

11 Wassily Kandinsky. Bavarian Mountains with Village . . . . . . . . . . . . . 28

12 Wassily Kandinsky. Composition IV . . . . . 30

13. Wassily Kandinsky. Sma11 Dream in Red . . . . 31 


\section{CHAPTER I}

\section{INTRODUCTION}

Much has been written on the separation of art from life, of the division between aesthetic and everyday experience in the contemporary world. ${ }^{1}$ This problem is of particular concern to a teacher in a democratic society, whose responsibility it is to provide a meaningful art program for al1 students. If one's philosophy is based on the conviction that art is the result of experience which needs to be understood and expressed, then one must be concerned not only with art forms but with the relationship of those forms to the human condition. Moreover, it is particularly valuable, when teaching adolescents, to have a humanistically based teaching philosophy. It is in the transition from the child's unconscious approach to art to the consciousness of adulthood that confidence is often lost, and the cessation of artistic activity frequently follows. An art program based on an acknowledgement of adolescent experience in particular, and of the human experience in general, can counteract some of the fragmentizing and disunifying aspects of this crisis period.

This thesis is an attempt to implement this philosophy in two ways: by setting forth a curriculum which emphasizes 
preliminary experiences for each art product and by interweaving these preparatory studio procedures with material from the history of art. Thus, it is hoped that the student's work will take place in the context of personal meaning and historical understanding.

A single genre, landscape painting, is the subject of all the teaching units, or chapters. Landscape painting was chosen as a result of the author's interest in the subject as we11 as a reflection of the recent intensification of society's interest in the environment. The history of Iandscape painting reflects man's changing relationship to nature. "Its rise and development since the middle ages is part of a cycle in which the human spirit attempted once more to create a harmony with its environment." 2

Each chapter of the thesis deals with a different approach to the world of nature. The second chapter considers landscape painting as a means of gathering knowledge about the natural world; the third concentrates on the expression of feeling through landscape painting. The 1 andscape as a source of ideas is the subject of Chapter IV. The double emphasis of the thesis, the combination of studio work and the history of art, is reflected in the structure of the chapters, each of which contains two sections. The history of art is the basis of the first section of each chapter. As the students move from one kind of 1andscape experience to another, they also move through time from the Renaissance to the modern world. A single artist 
was selected to represent each period in order that the students might feel the relationship between the 1 ife experiences of the artist and the quality of his work. Chapter I deals with Leonardo da Vinci as a man of knowledge of the Renaissance. The expressive painting of van Gogh is considered in Chapter III, and Chapter IV examines the conceptual approach of Wassily Kandinsky. The presentation of the material from the history of art is not necessarily in the exact form that would be introduced to the students. These sections are to be considered assemblages of relevant material from which one could draw as needed during the course of each teaching unit. In spite of the chronological sequence, the emphasis of this approach is not meant to be a comprehensive history of art nor does it necessarily cover the major periods of landscape painting. Rather, it is hoped that the students might sense that these works are based on actual human experience and that this experience changes with the passage of time, bringing new uses for art, new meanings, and new forms.

The second section of each chapter describes activities designed to evoke the students' own experiences and to actualize them in painting form. Included here also is material on the language of art dealing with an, aspect of color theory. An effort has been made to organize the material on color in terms of its appropriateness to the main idea of the chapter. Light and dark values are dealt with 
as part of the unit on "Landscape as Knowledge." Hue contrast and complementary colors accompany the unit on "Landscape as Feeling," and Chapter IV, "The Landscape as Concept," includes material on color relativity.

At the end of each chapter, and based upon it, is a specific lesson plan. Each plan is arranged to cover a month's work of a secondary school class, meeting three times a week for fifty minutes. This format was adopted so that the reader could use the thesis either as a general demonstration of an approach to art education, or as a specific guide from which to teach. 
HISTORY OF ART: THE RENAISSANCE, LEONARDO DA VINCI

During the Renaissance one looked at a painting as through a window. ${ }^{3}$ The view of the world so glimpsed was primarily occupied by the human figure, for landscape painting per se did not exist. The landscape was considered subordinate to human action and a background for it. Nevertheless, one of the Renaissance achievements was the creation of a coherent, illusionistic landscape space. Linear perspective, overlapping, aerial perspective, and varied intensities of light and color were the means used to construct a satisfying space 4 in which to place the figure. The Renaissance artist was challenged to reconcile this spacial unity with a fidelity to naturalistic detail, for the urge to investigate the real world became so intense during the Renaissance that some Italian Renaissance painters have been considered men with a "gift for science who took to painting for the purposes of research." 5 Thus, artists of this time struggled to understand and to observe the world around them and to find a unity between man and the world in which he dwe1t. 
The story of the Renaissance artist, Leonardo da Vinci is one which can illustrate for the student how an artist can use his work to make scientific observations. As the student struggles to integrate his knowledge and express it in a visual form, he might find a point of contact in the life of a man who made the effort five hundred years ago to do the same and who wrote, "True painting is a science, the true-born child of nature. For painting is born of nature." 6

of illigitimate birth, Leonardo spent his first years in the countryside with his peasant mother, "watching the 1izards and glow worms and other strange small creatures,"7 giving him a lasting interest in organic life which was exceptional for his time. Although Leonardo was sent to school by his father, his education was scanty and he was basically a self-taught man. He has been characterized as lonely and alienated, but Vasari describes the youthful Leonardo as beautiful, brilliant, and complex, known for his charm of conversation and physical grace. ${ }^{8}$ He speaks of Leonardo's tenderness toward animals, telling how he would purchase birds at the market in order to release them from their cages, letting them fly into the air. ${ }^{9}$

In his youth Leonardo was fond of climbing the hills surrounding Florence. The Valley of the Arno of 1473 (Fig. 1) may have been done on such an excursion. It is drawn with lively broken strokes but they are firmly based on visual experience. The separation of soil and underlying 


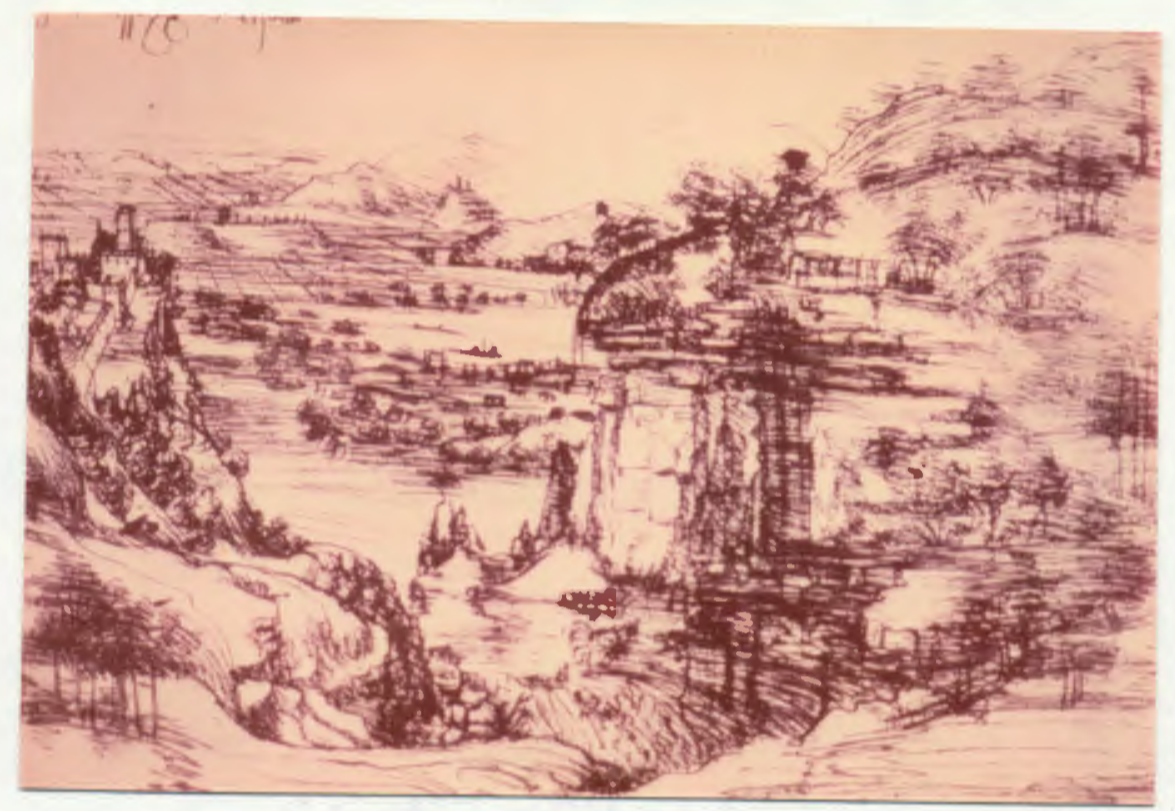

Figure 1. Leonardo da Vinci, The Valley of the Arno rock and the eroded indentations of the cliffs are carefully noted. Although the viewpoint from the raised ground, overlooking the flat plain, is based on a traditional formula, 10 Leonardo looked at nature with fresh and observant eyes. Un1ike many other artists of his time, he was not content to rely on other authorities to satisfyr his need for information; he trusted primarily his own sensory experience. He wrote, "but it seems to me that all sciences are vain and ful1 of errors that are not born of experience."11 Many of his drawings are based on botanical studies like the Lily of 1479 (Fig. 2) and Study of a Plant of 1506 (Fig. 3). However, the range of Leonardo's investigations was immense; his notebooks on landscape alone are filled with observations 


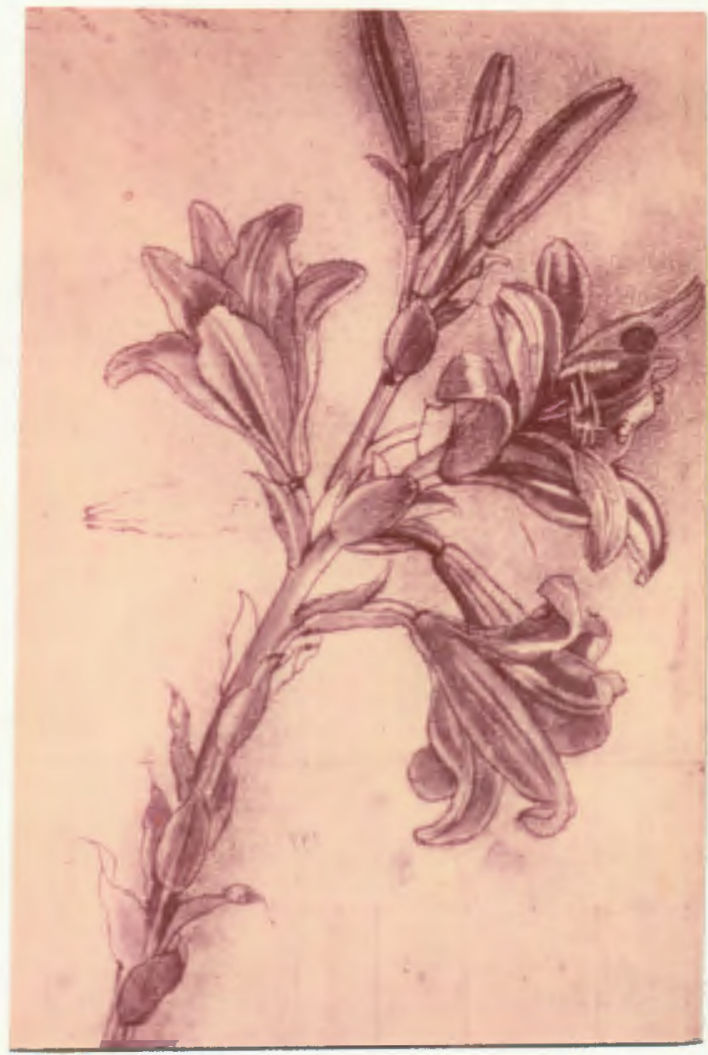

Figure 2. Leonardo da Vinci, Lily.

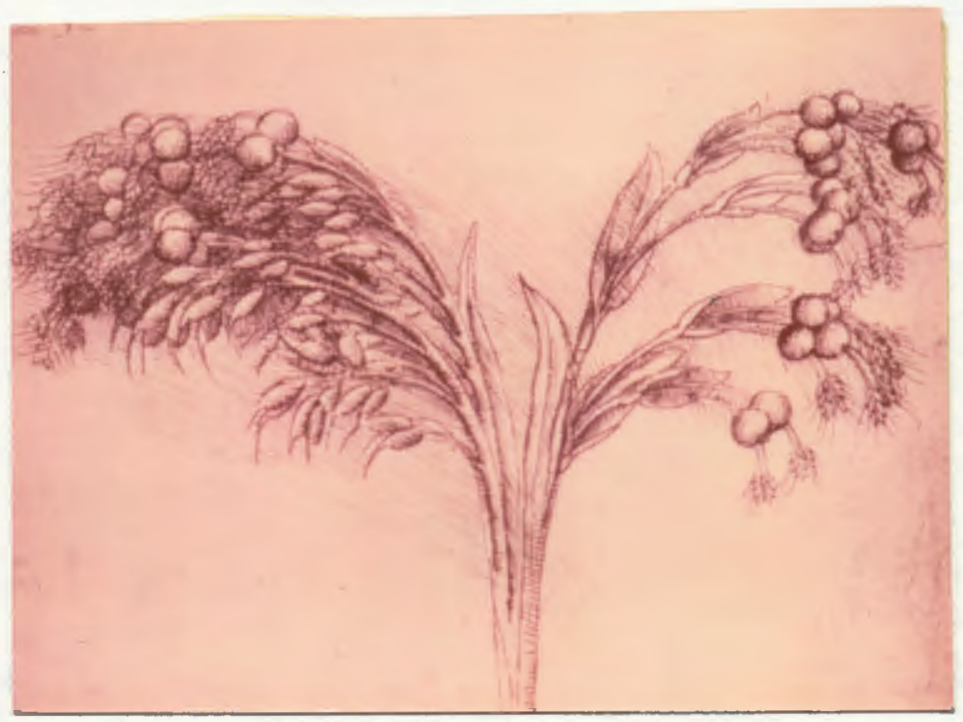

Figure 3. Leonardo da Vinci, Study of a Plant. 
not only of plant forms but of clouds, heavenly bodies, geological informaion, (Fig 4) and the properties of water.

As one might expect, Leonardo communicates considerable landscape information in his major art works. While his fascination with the workings of nature and with 1 andscape is largely relegated to the background in his paintings, in the Madonna of the Rocks of 1480 (Fig. 5) 1andscape forms figure prominantly. In spite of the glow of Leonardo's soft light and the pervasive atmosphere of the painting, the leaves and flowers in the foreground (Fig. 6) exhibit the same naturalism as the drawings. They speak of the years devoted to the study of plants by the man who has been considered the founder of botany. Likewise, the rock formations (Fig. 7) are careful1y observed, recorded, and

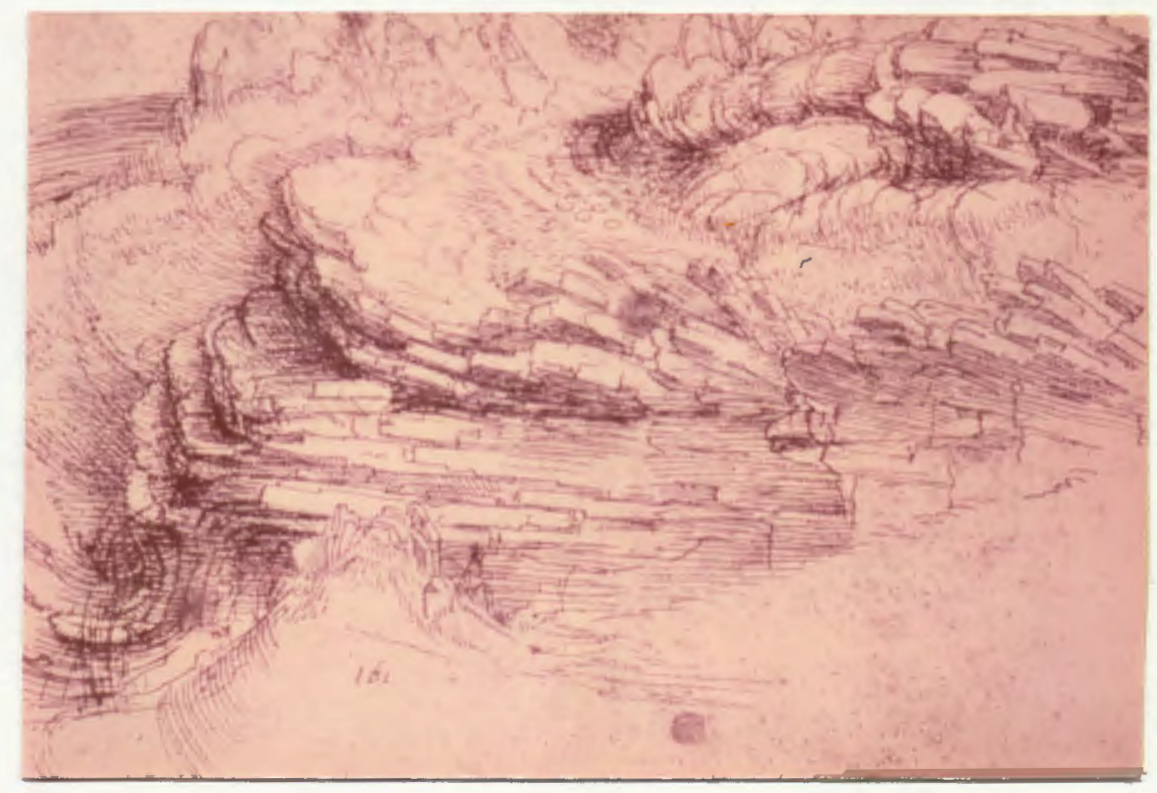

Figure 4. Leonardo da Vinci, Study of Rocks. 


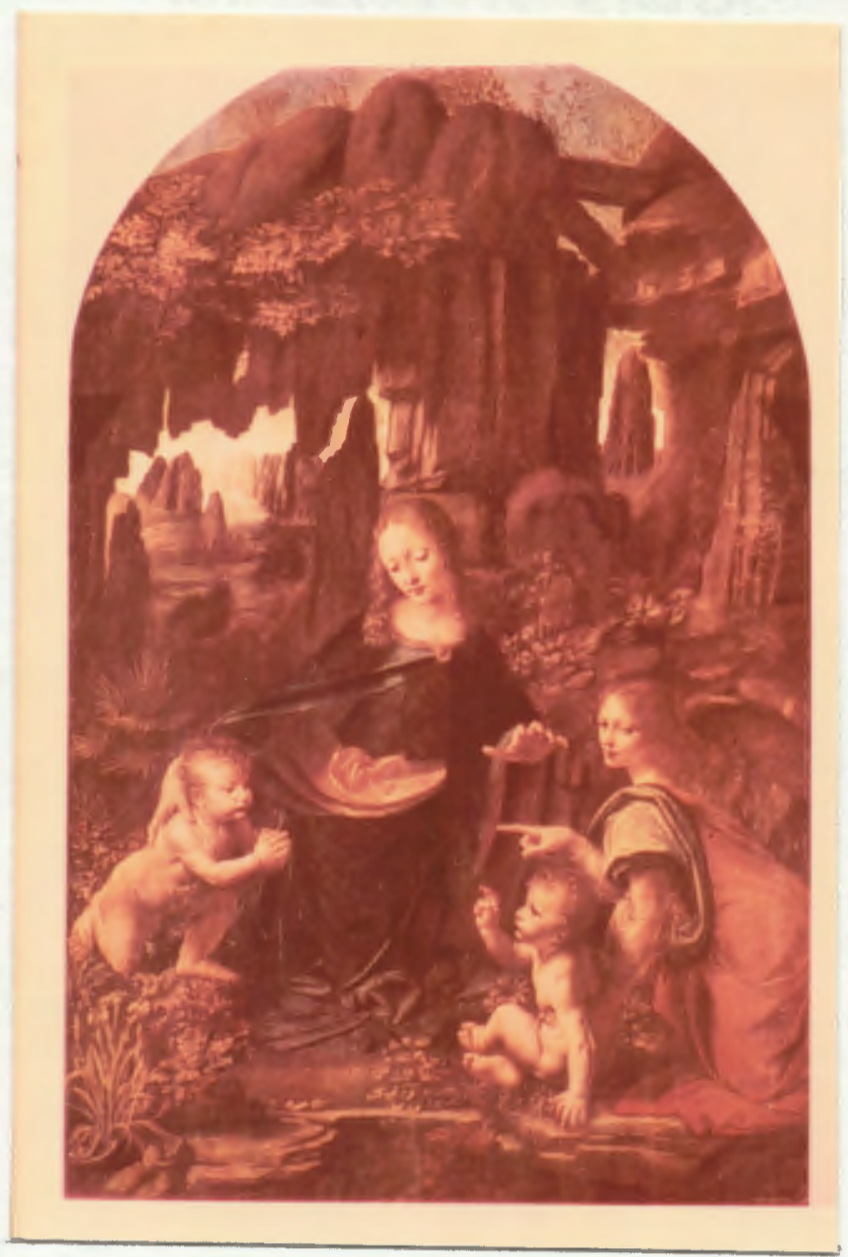

Figure 5. Leonardo da Vinci, Madonna of the Rocks. 


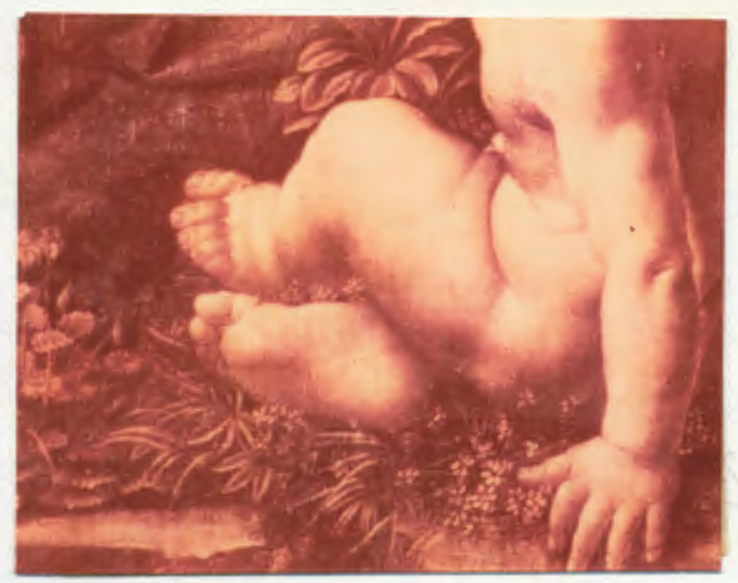

Figure 6. Detail

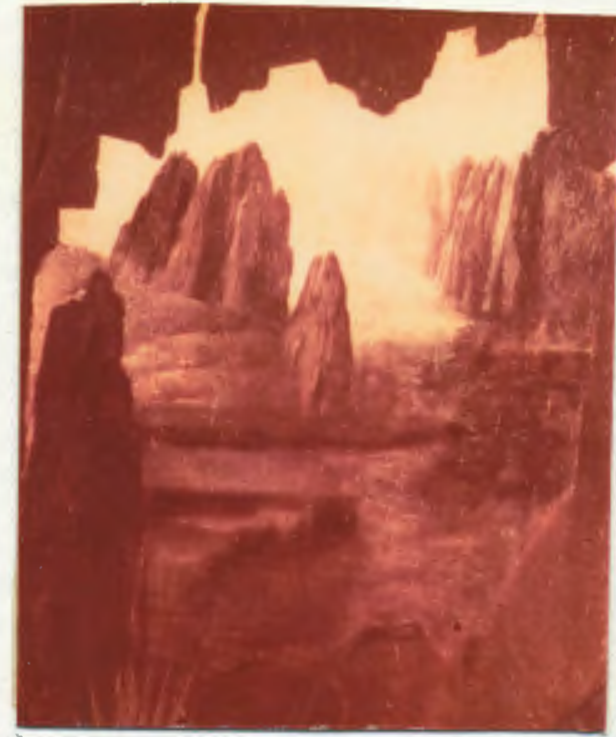

Figure 7. Detail

articulated by light and dark values.

The interpretations and meanings surrounding the Madonna of the Rocks are rich and complicated. However, in addition to these atmospheric and emotional elements, the painting reflects the investigative experiences of one of the most knowledgeable minds of the Renaissance.

\section{CLASSROOM PROCEDURES AND STUDENT EXPERIENCES}

Much of childhood is spent, in one way or another, gathering information about the world. During preadolescence, children become particularly curious and investigative. Lowenfeld describes this phase as the age of realism. ${ }^{12}$ By adolescence, many people have developed considerable expertise as young scientists, resulting from school courses or personal enthusiasms. It is less likely, 
however, that students would have conceived this information as a source from which to draw artistic ideas. The following are suggestions for stimulating student awareness of aesthetic possibilities arising from his or her knowledge of the natural world.

Each student should decide upon an area of interest he/she wishes to pursue and keep a notebook recording information obtained and observations made. These can be verbal descriptions, pictures, or drawings. Some of the possibilities would be geological studies such as rocks, caves, mountains; botanical studies; studies of weather and sky formations; water and water movements; the unseen microscopic world; and the man-made landscape, gardens and farms, building techniques, human patterns of movement. Any of these might be combined to show relationships between them. Such notebooks could be used as resources for sharing information with other students and as a source of painting ideas.

Possible classroom displays might include scientific notebooks and drawings such as those of Leonardo da Vinci or other natural scientists. Photographs of landscape forms could be displayed which have been selected to show information and detail, e.g. the stratification of rock, the growth patterns of plants, etc. Students and teacher could exhibit in the classroom collections of rocks, plants, and natural forms from which further studies could be made. 
A microscope and telescope could be borrowed for specialized observations. Films on nature and landscape can lend immediacy to the knowledge-gathering process. The art classroom would, thus, become an environment providing informationgathering experiences.

As the students participate in experiences and as their interest becomes focused, they can be encouraged to make preparatory drawings or sketches for a painting, or a series of paintings, based on some aspect of their know1edge of the natural world.

As these studies progress, a consideration of light and dark values would be undertaken. The students would be encouraged to experiment not only with the range from black to white, but with tints, tones and shades ${ }^{13}$ of color. When these concepts become familiar, experiences of value matching can be undertaken. For instance, students might try to make a value study of a Leonardo painting, such as the Madonna of the Rocks, of other examples from the history of art, or even from photographs of the natural world. It is important to bring out many possible uses and meanings of light and dark values. During the Renaissance these values were seized upon as a way of creating the illusion of solid objects in a rational space. Leonardo was fascinated with the properties of 1 ight and shadow, writing six books on the subject. Light and dark values, however, can be used separately from illunimation as a means to define shape, to separate objects, to detach planes, to render texture. 
A familiarity of values and their possibilities should provide the students with the means to articulate their researches of the natural world. Each student has a personal array of experiences of 1 ight and dark, and each should be encouraged to select consciously a value range for his landscape studies and paintings. Although the choice of media for these paintings might be determined by the students' own expressive needs, the unit plan will be to stress communication by means of light and dark values with some restriction on the range of hue.

At the termination of the section dealing with landscape as knowledge, the students could share their work by means of a classroom presentation or exhibit. The inclusion of some of the raw data such as the notebooks, collections, etc. juxtaposed with the finished paintings would be an interesting display.

\section{LESSON PLAN FOR CHAPTER I I}

\section{$\underline{\text { Procedures }}$}

Materia1s and Sources

\section{First Week}

Day 1 . Introduce the subject of landscape painting. The students decide on area of concentration and examine scientific publications as sources of ideas.

Magazines: Pacific Search, Smithsonian, Nationa1 Geographic, Audubon Society, and Scientific American

Books: Witness to Nature by Alfred Eisenstae dt, The New Landscape by Gyorgy $\overline{\mathrm{Kep}} \mathrm{s}$ 


\section{Procedures}

Day 2. Students and teacher bring and arrange collections of rocks, wildflowers, insects, etc., as well as nature photographs. (This activity can be continued at intervals throughout the unit.) Show the movie, Trees if the Pacific North-

Day 3. Introduce idea of keeping a notebook and discuss expectations. Each student must complete drawings from nature of ten examples in his field: ten plants, ten types of rocks, ten cloud formations, ten views of water motion, etc. Optional inclusions: written information and nature photographs. Show movie, World in a Marsh.

\section{Second Week}

Day 1. Discuss 1 ife and work of Leonardo. Students work on notebooks.

Day 2. Students work on notebooks. Introduce idea of light and dark values. Students practice making samples of darker and lighter values.

Day 3. Students make tonal drawings of material from their notebooks. Look again at Leonardo's tonal drawings

\section{Materials and Sources}

Movie: Trees of the Pacific Northwest

Notebooks of Leonardo da Vinci

Bond drawing notebook, 9" $\mathrm{x}$ 12", \#4B pencil, gum eraser

Movie: World in a Marsh

Slides: Valley of the Arno, Lily, Study of a P1ant, Stratified Rocks

Black conté crayon, $18^{\prime \prime} \mathrm{x}$ 24 " newsprint

B1ack conté crayon, $18^{\prime \prime} \mathrm{x}$ 24" newsprint

S1ides: Va1ley of the Arno, Lily 
Procedures

Third Week

Day 1. Students practice making dark and light values of one color. Discuss Leonardo's use of light and dark.

Day 2. Students start a painting.

Day 3. Paint.

Fourth Week

Day 1. Paint.

Day 2. Paint.

Day 3. Clean up, arrange an exhibition, discuss students' work.
Tempera paint: black, white, one color, $18^{\prime \prime} \mathrm{x}$ 24 " bond drawing paper

S1ide: Madonna of the Rocks

Tempera paint: black, white, one color, $18^{\prime \prime} \mathrm{x}$ 24 " white construction paper 


\section{THE LANDSCAPE AS FEELING}

HISTORY OF ART: THE NINETEENTH CENTURY, VINCENT VAN GOGH

Since the middle ages, man has become increasingly aware of himself as a unique and separate person, but it was during the nineteenth century that man's rising sense of individualism became a more widespread and conscious force. The artist then

began to explore the strange universe that he carries with him, inside himself, and he began to make discoveries about himself. He acquired a new sense of himself, his own inner uniqueness. Art now seemed to him the . . . means of giving permanent expression to that unique self. 15

The precise rendering of the landscape as part of external reality was no longer a major objective for many artists. Thus, nature became a source of images through which the artist could express himself, a point of departure to reach the inner world of feeling and fantasy.

Of the artists of the nineteenth century, the story of Vincent van Gogh is one of the most poignant. His entire adult life was a struggle for personal integration and expression. Working three hundred years later than Leonardo, van Gogh also studied the natural world with a passionate intensity. His love of nature was an early and 
profound feature of his character. ${ }^{16}$ Seizing upon his immediate sensations, van Gogh preferred to paint directly from nature, even in wind and scorching sun; although it was not scientific curiosity which drove him, but a search for landscape forms corresponding to his need for self-expression. He wrote his brother: "The emotions are sometimes so strong that one works without being aware of working."17

His passionate temperament had not found fulfillment in a patchwork of earlier occupations of art dealer, teacher, and evangelical minister. Art became for him a long-sought means of personal expression and self-realization.

In 1886 van Gogh's search for a means to become a painter brought him from Holland to Paris. Here, he became familiar, through the impressionists, with the world of light and color. However, van Gogh's search for ultimate values went beyond the impressionists, causing him to use color in its more intense and pure state. For him color. conveyed what he felt about the things he painted and what he wished others to feel. 18 He wrote, "Color in a picture is like enthusiasm in 1 ife. ${ }^{19}$ And in order to find a landscape corresponding to that enthusiasm, van Gogh left Paris for the south of France in 1888. In Arles, his work emanated vitality and joy. There he painted his famous sunflowers as well as countless landscapes in the dazzling southern light. 
Le Pont de Langlois (Fig. 8) is primarily composed of highly saturated blues and yellows. Against the intense blue sky is sillouetted the bridge framework of varying hues and intensities of yellow. It is in the use of intense, yet nuanced, color that van Gogh's highly developed sense of color can be seen. The most intense color becomes one element in a scale of intensities. ${ }^{20}$ The range of saturations of yellow in the stonework becomes a color bridge between the sun-1it yellows of the bank and the blues of the water. Van Gogh at this point in his life was fascinated with yellow, and described it as pure light and love, and with blue, which conveyed to him an infinity of celestial and inward space. 21

This sense of joy, as expressed in Le Pont de Langlois, was not long lived for van Gogh, for in 1889 after several breakdowns, he became a self-committed inmate in the asylum of Saint-Remy near Arles. The Park of the Asylum (Fig. 9) is to a large extent an investigation of his own emotional state.

You will realize that this combination of redochre, green saddened by grey, and the use of heavy black outlines, produces something of the sensation of anguish.....moreover the effect of the great tree struck down by lightning and the sickly greeny pink smile of the last flower of autumn merely serve to heighten this idea. 22

The painting reflects the interest in contemporary colors which had so preoccupied him in Arles, and he creates with the violet-gold and red-green a correspondence with his 


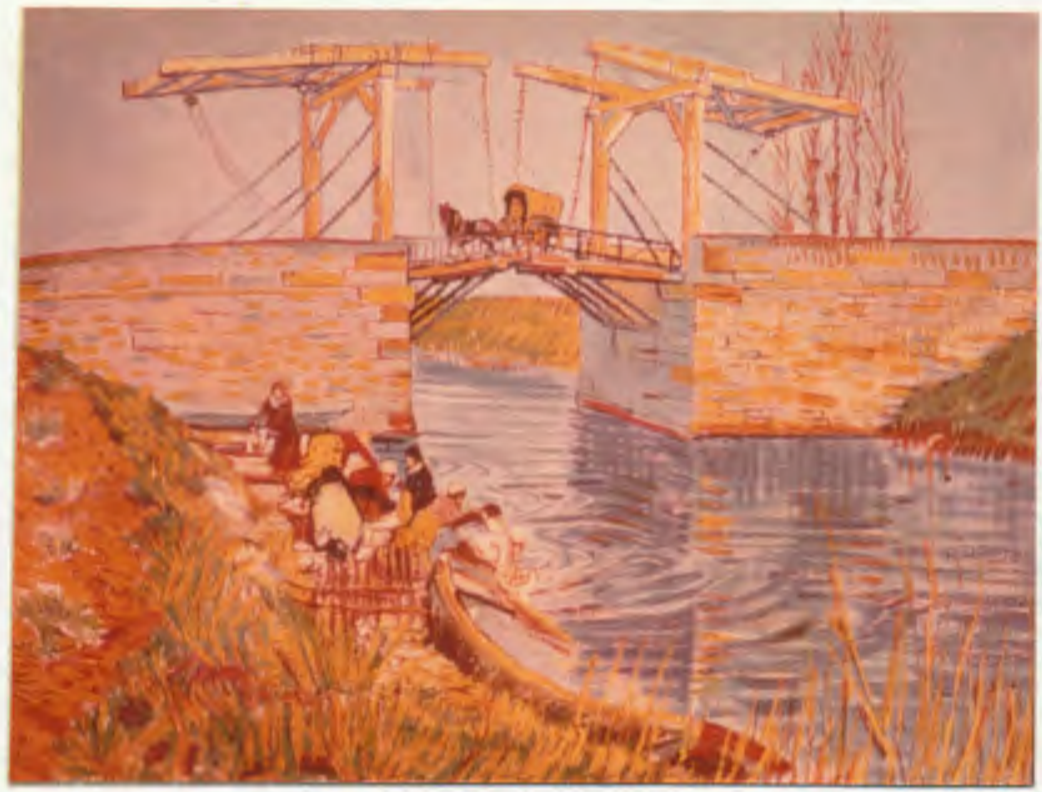

Figure 8. Vincent van Gogh, Le Pont de Langlois.

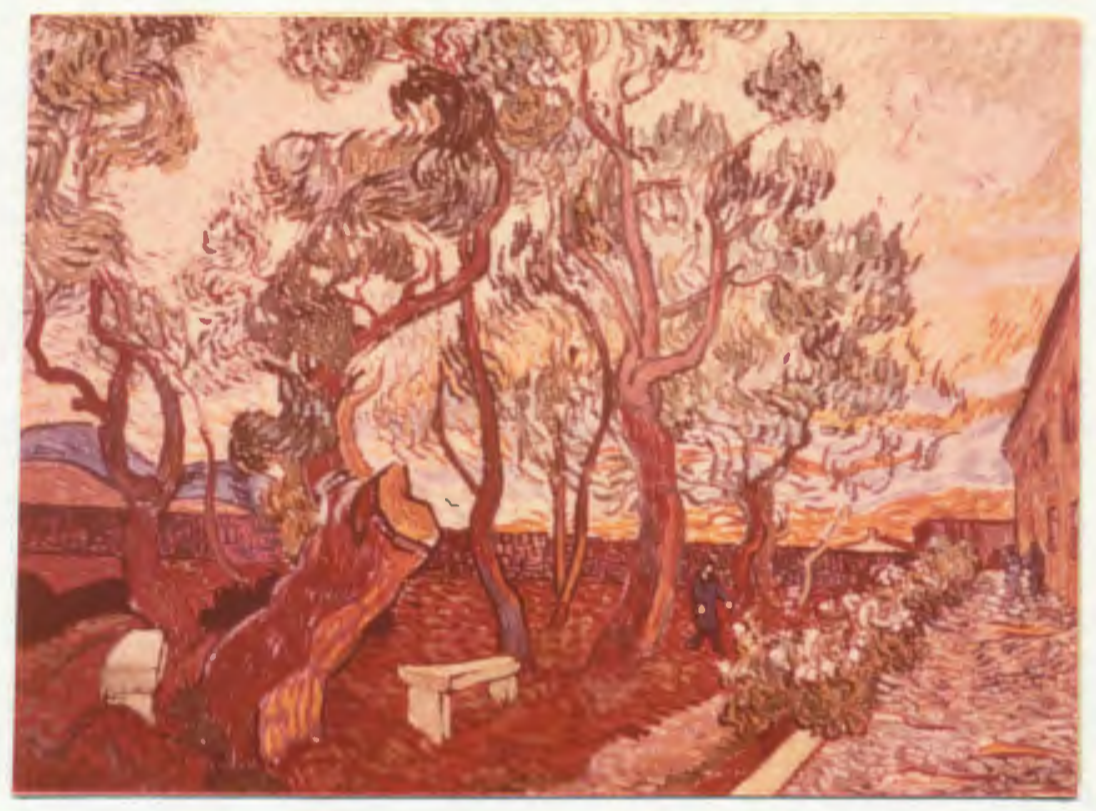

Figure 9. Vincent van Gogh, The Park of the Asylum. 
stricken condition. The brush strokes, always a vigorous graphic element in his work, now become intensely expressive. Although the brush strokes of the Park of the Asylum express agitation, they are in The Starry Night (Fig. 10) a veritable whirlwind. His attacks had continued at Saint-Rémy.

Those were dark days again of complete blackout, anguish and terror, hallucinations and fear, of torpor or agitation, of silence or rage. And the endiess nights were worse. Nothing but delirium, despair, resignation, suffering.

The Starry Night expressed van Gogh's longing for infinity 24 but his ongoing experiences of darkness, anguish, and delirium are also contained in the painting. These emotional effects are heightened by the contrasting of the short, straight strokes of the town with the flowing rhythms of the sky. A series of contrasting colors is present but the deep blue has become the overwhelming note.

The connection between van Gogh's life and his art was immensely acute. He was intensely observant and passionately involved with the landscape, which in his paintings becomes invested with his own tumultuous emotions. 


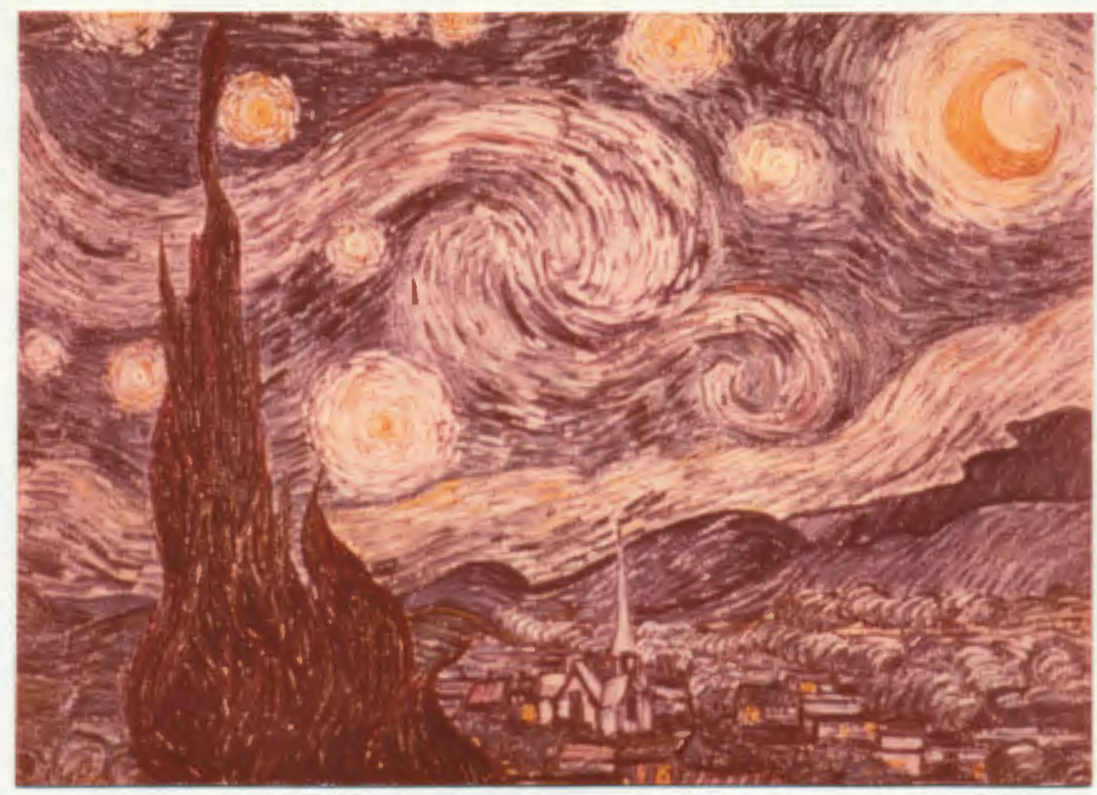

Figure 10. Vincent van Gogh, The Starry Night.

\section{CLASSROOM PROCEDURES AND STUDENT EXPERIENCES}

If, in our culture there is a period in the life of the individual which is generally regarded as emotionally charged, concerned with self, and fraught with crisis, that period is adolescence. The onset of physical maturation and the uncertainty of future adult roles creates for the young person a "crisis of identity."25 Thus, investigation of the self, experimentation with different modes of being, and the search for forms of personal expression become particularly appropriate at this age.

In order to find personal meaning in the natural world and to arrive at the expression of that meaning through landscape painting, several preliminary classroom experiences are suggested. The class might, as an introduction, 
focus on the emotional content of and the possibilities of personal response to other art forms. Musical selections could be played to stimulate class discussions about the feeling conveyed. Descriptions of landscapes from literature could be selected with regard to emotional content and read to the class as the basis of similar discussions. The classroom. itself, by means of special lighting or stage props, if available, could be altered in mood. Walks could be arranged to observe the varying emotional effects of nature upon the individual.

Throughout this section the technical emphasis would be on hue variations and hue relationships. It would be appropriate at this point to introduce experiments of color mixing and the concept of contrasting or complementary colors. Studies could be made of the color relationships of van Gogh's paintings or other painters, like the Fauves, who use color expressively. Comparisons could be drawn with the studies undertaken in the preceding chapter which relied primarily on light and dark variations.

A 1ist of personal feelings could form the basis for a series of small color compositions. For example, the student could make color studies which would attempt to express his idea of anger, grief, joy, nostalgia, etc. One of these could be selected as the color scheme of a landscape painting. 
A final exhibition could then be arranged, grouping paintings together which attempted to express similar fee1ings, thus stressing the' individual interpretations of the emotional themes.

\section{LESSON PLAN FOR CHAPTER III}

Procedures

First Week

Day 1. Discuss emotional possibilities of landscape and color. Students experiment mixing secondary and tertiary colors.

Day 2. Read or hand out descriptions of landscapes from literature. Students paint color studies to express the same feelings. Discuss contrasting quality of colors.

Day 3. Discuss van Gogh, his iife and work, emphasizing his use of color.

\section{Second Week}

Day 1. Students experiment with varying brush strokes. Students paint to music with attention to the mood of the music.
Red, blue and yeliow tempera paint, $18^{\prime \prime} \mathrm{x}$ 24 " bond paper

Appropriate landscape descriptions from literature can be found in Modern Landscape Painting by Pier Car1o Sant

Tempera paint and $18^{\prime \prime} \mathrm{x}$ 24 " white construction paper

S1ides: Le Pont de Langlois, The Park of the Asylum, The Starry Night

Tempera paint and $18^{\prime \prime} \mathrm{x}$ 24 " bond paper

Music: Pastoral Symphony by Beethoven, Is $1 \mathrm{e}$ of the Dead by Rachmaninoff, Gaiete Parisenne by offenbach, sacad Suite by William Wa1 ton 


\section{Procedures}

Day 2. Look again at slides. of van Gogh, emphasizing brush strokes. Show movie, Vincent van Gogh.

Day 3. Go for a walk. Each student makes a sketch based on a predominant color.

Compare results in regard to emotional content.

\section{Third Week}

Day 1. Using landscape from Chapter II, the students paint it again in color, the choice of which is determined by a strong feeling.

Day 2. Paint.

Day 3. Continue painting. If finished, students could start a second painting, based on contrasting colors to the first.

Fourth Week

Day 1. Paint.

Day 2. Paint.

Day 3. Clean up, arrange an exhibition, discuss student work.
Materials and Sources

Slides: The Park of the Asylum and Starry Night

Movie: Vincent van Gogh

craypas and $12^{\prime \prime} \times 18^{\prime \prime}$ bond paper

Tempera paint and $18^{\prime \prime} \mathrm{x}$ 24 " white construction paper 


\section{CHAPTER IV}

\section{THE LANDSCAPE AS CONCEPT}

HISTORY OF ART: THE TWENTIETH CENTURY: WASSILY KANDINSKY

In the twentieth century man's view of himself and his relationship to nature underwent drastic alterations. A science developed which no longer depended, as it did in Leonardo's time, entirely on observations of a perceivable world, but also on calculations regarding an unseen one, and which articulated revolutionary concepts of space, time, matter, and energy. Freud's theory of human nature focused not on the outer, visible aspects of man but on the inner domain of the unconscious. As faith in the reality of the tangible and visible has faded, the traditional values of naturalistically representing the observable world have become less meaningful to many painters.

Artists of this century have responded to man's changing relationship to nature in a variety of ways. Some have searched for new equivalents for their perceptions of nature. Others have turned inward, investigating themselves, producing works of personal gesture and private symbolism, in which "nature enters the work of art subsconsciously in the act of painting."26 others have felt that formal considerations--the relationships between lines, shapes, colors, 
textures, and surfaces--express the ultimate laws of nature. Genera11y, the twentieth century has been characterized by a freedom in which artists have conceptualized reality in new ways, to create their own realities. These changes have not made it easy for young people to relate to a set of values, to find an ideological commitment. To some degree each generation in this century has had the task of reevaluating and reconstructing value systems.

In spite of its apparent difficulty and complexity, the work of Wassily Kandinsky could be of interest to the adolescent student as an example, in:visual form, of one man's struggle to find new values and to overcome the force of materialism by asserting the primacy of man's inner nature. Some art historians have felt that there is a connection between modern man's despair and restlessness and the tendency toward abstract art, ${ }^{27}$ and in fact Kandinsky wrote: "When religion, science, and morality are shaken and when outer supports threaten to fall, man withdraws his gaze from externals and turns it inwards." 28

However, Kandinsky's gaze as a youth was very much on the outer world. He had a remarkable visual memory and could recall all his life vividly colored scenes from his Russian boyhood. In spite of a youthful interest in painting, Kandinsky, the son of a Russian businessman, entered the university to study law. Thus, like van Gogh, he was in his thirties when, forsaking a distinguished legal career, 
he began again as an art student. During these student and post-student years, he was "intoxicated by nature" 29 and tried to express everything through color. As a young man he had discovered the charm of the brightly colored Russian folk art. Some of the enchantment of these early experi: ences is found in Bavarian Mountains with Village (Fig. 11) painted in 1909 while Kandinsky was living in Germany. This landscape painting is composed of clearly recognizable elements. However, the color is intensely brilliant, liberated from the limits of naturalism. Although organized within a conventional landscape space, the forms of the hills, mountains, and houses have been simplified and intensified. The composition can easily be seen as a relationship among colored geometric forms, primarily triangles.

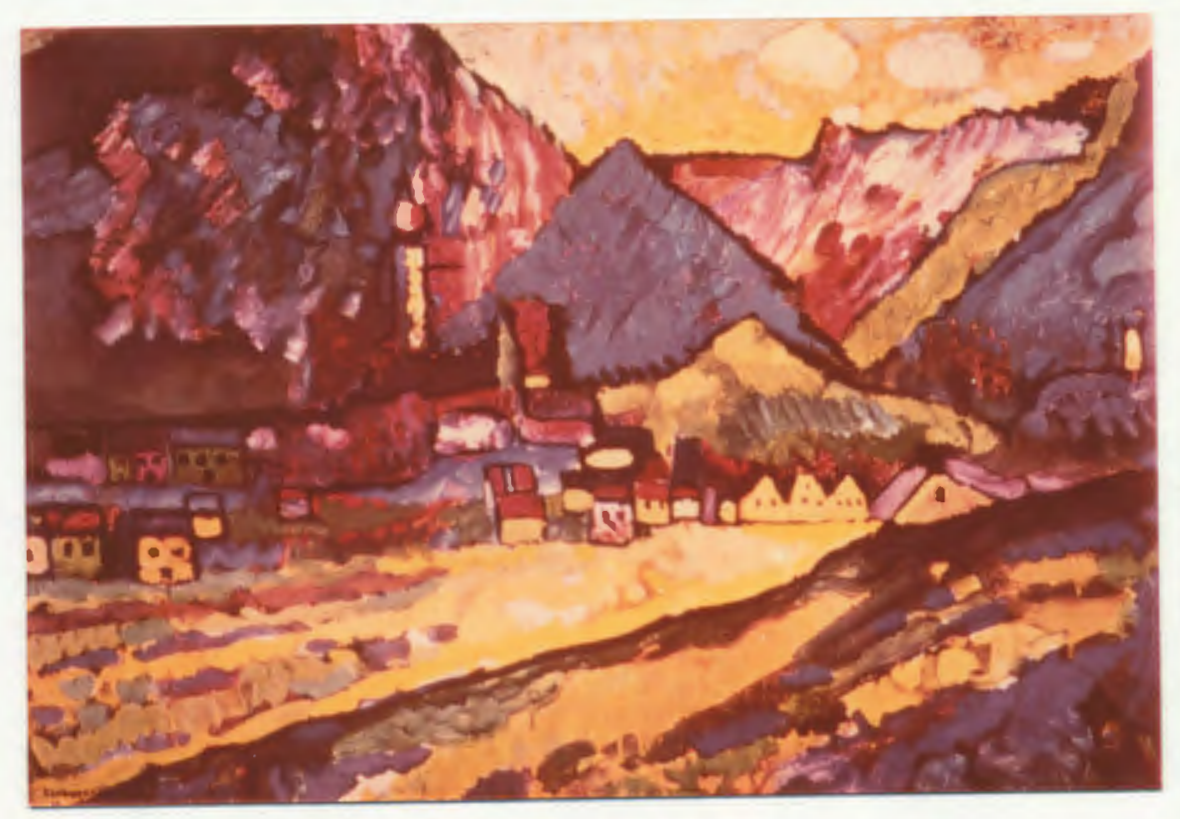

Figure 11. Wassily Kandinsky, Bavarian Mountains with Village 
Kandinsky recounted an experience he had about this time, of coming into his studio at twilight and finding a painting of dazzling beauty on his easel. He was profoundly affected by the shapes and colors in the picture but unable to make out a subject. His realization that the painting was resting on its side confirmed his belief in the redundancy of traditional subject matter. 30 Keenly aware of the new philosophic and scientific climate of his age, Kandinsky became convinced that representational art was dead. A new subject matter was needed, based on inner experience which could be communicated through an abstract language. However, at this point in his development, Kandinsky did not wholly reject material objects in his paintings, provided that their choice followed the principle of inner necessity. 31

In Composition IV of 1911 (Fig. 12), the shapes, lines, and colors, although derived from his earlier involvement with landscape, have begun to take on a life and meaning of their own. Space is achieved not in traditional ways, but by the introduction of a large quantity of white, which Kandinsky described as having the qualities of infinity and of a silence filled with possibilities. ${ }^{32}$ Like many of van Gogh's paintings, Composition IV is constructed around a blue and yellow color scheme. Whereas van Gogh focused on the emotionally expressive aspects of colors, Kandinsky arrived at color meaning through an analysis of 


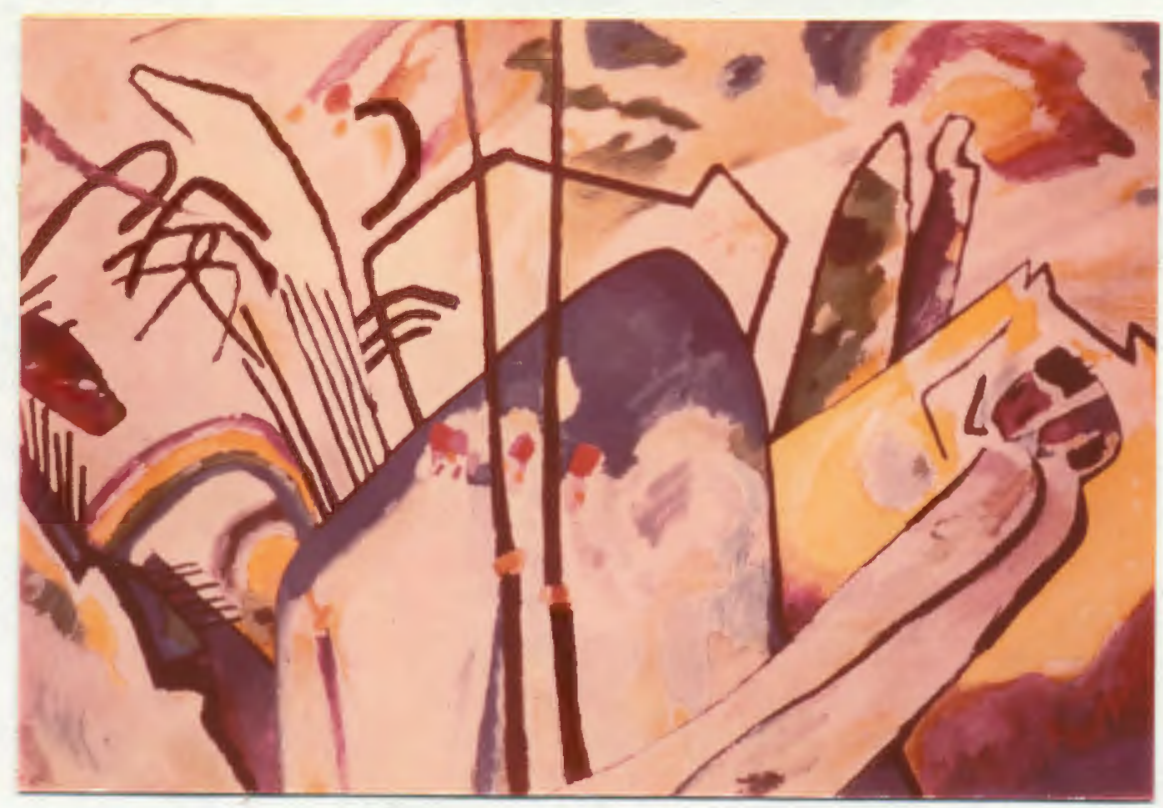

Figure 12. Wassily Kandinsky, Composition IV.

color properties. Yellow and blue, he maintained, form the poles of warm and cold; yellow strains toward the spectator and tends to spread out from its center, whereas the blue retreats from the spectator and turns in upon its own center. Kandinsky felt that yellow affects us as earthly, brash, importunate; blue as restful and tending toward quiescence and depth. 33 . The blue mountain in Composition IV provides a central point of repose among the agitation of the surrounding forms and colors. Rather than as a descriptive element of the natural world, color is used for its own qualities and meanings.

Although Composition IV has the quality of being abstracted from nature, Kandinsky's later paintings seem to have very little naturalistic reference. Sma11 Dream in Red 
of 1925 (Fig. 13) contains many formal, non-representational elements. Kandinsky was fascinated by the circle during these years. "I love the circle today as I formerly loved the horse -- perhaps even more, since I find more inner potentialities in the circle." 34 He saw lines in terms of forces; zigzag lines as two alternating forces, curves as the result of unequal simultaneous forces, etc. Much of the dynamism of Sma11 Dream in Red comes from the combination of these linear forces. However, even in this comparatively late work, mountain shapes occur as a kind of inescapable element and are compositionally related to the formal elements of the painting.

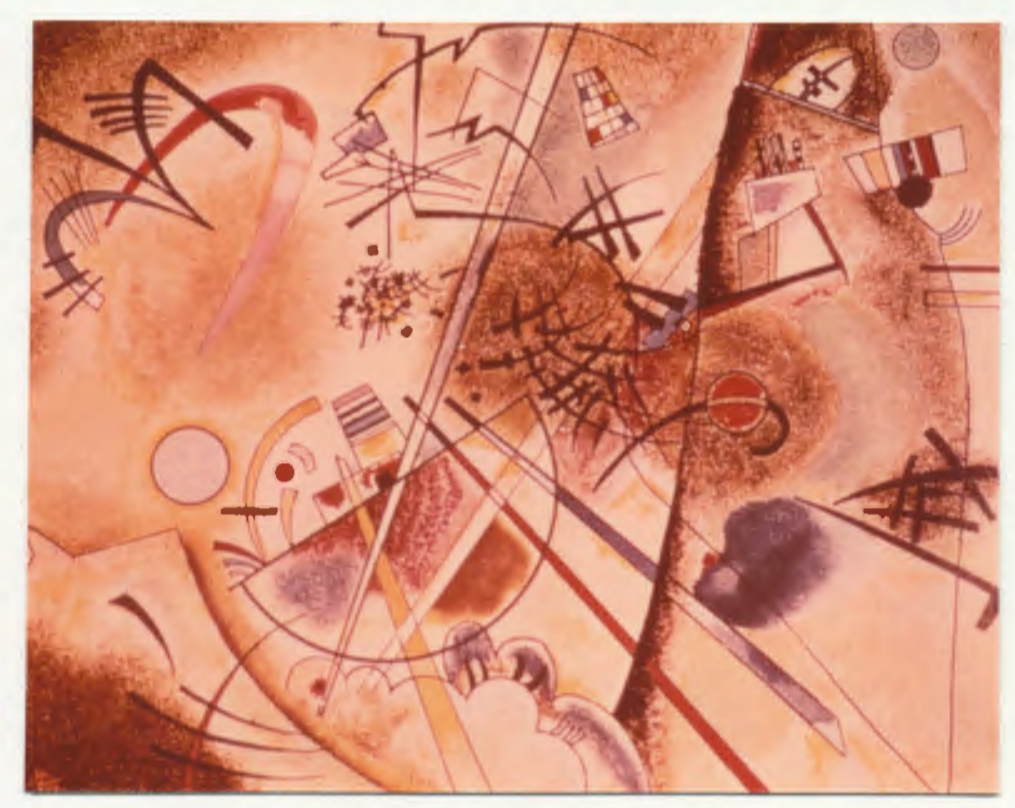

Figure 13. Wassily Kandinsky, Sma11 Dream in Red. 
Thus, Wassily Kandinsky was an intensely visual man, who looked inward as well as outward, and who searched for meaning in abstract forms and concepts. Intuitive as well as reasoned, he endeavored to create in his paintings an idea of the universe which would reveal its basic meanings more clearly and more deeply than did the world he saw around him.

\section{CLASSROOM PROCEDURES AND STUDENT EXPERIENCES}

If it is true that "art serves as a vicarious substitute for the genuine and intense involvement with life that is withheld from adolescents by our culture" 34 then it would seem important that the adolescent find some connection between himself and contemporary art. Care must be taken, however, to avoid teaching a "style," and to avoid providing students with artistic devices merely so that their work may appear "modern." Rather, one should seek to involve the students in the process of concept formation. This unit will attempt to focus on three sources of artistic concepts: the outer world of natural forms, the inner world of the students' associations, symbols, and meanings, and the formal elements of design.

There are innumerable procedures that could be used to stimulate the formation of conceptualizations of the natural world. The following suggestions are only a sample of the possibilities. The student could examine landscape drawing or landscape photographs for the occurence of simplified, 
geometric, and decorative shapes. Cut-paper collage studies could be made on this basis. The landscape could be reduced to a series of lines, representing directions of growth, forces in action, etc. The student's perception could be directed toward negative spaces, or the student could decide upon a single, typical quality of a landscape, e.g. roundness, slantedness or sharpness, and present a landscape study emphasizing this quality. Although all these studies involve a perceptual approach, it is hoped that the concepts would considerably affect the ways of seeing the natural world.

An alternate approach would be to focus, not on different ways of seeing, but on the concepts themselves. Without reference to a particular scene, students might create a generalized landscape condition such as a season, a climate, a terrain, or a combination of these. The idea of the landscape as a symbol could be discussed at this point.

The formal aspects of art, or the language of art, is another source of visual concepts. This section of the project would continue the study of color, emphasizing its relative qualities both in regard to other colors as well as to the other aspects of the language of art. Color studies can be undertaken to investigate hue and value changes on a color effectuated by surrounding colors. Experiments with warm and cool colors and their effects on each other could be conducted. The students could investigate the effects on 
color of differing shapes, sizes and placements. The spacial possibilities of color could be a source of experiment and discussion. Finally, the student could select a set of shapes and colors that have particular meaning for him and construct with them, if not a landscape, at least a study with a sense of environment or ambience.

As a conclusion to this unit the student should chose a study from one of the areas of concept building which have been undertaken and develop it into a painting or paintings. Finally, the students could discuss their finished work and that of their classmates in terms of the ideas which they contain.

\section{LESSON PLAN FOR CHAPTER IV}

Procedures

First Week

Day 1. Introduction. Show movie, Non-objective Art

Day 2. Each student chooses two colors and black and white and make 4" $\mathrm{x} 4$ " swatches of as many variations of mixtures of the two as time allows. Cut up and collect for class use.

Day 3. Using painted papers from the previous class, students do examples of color changes in relation to a color field: lighter, darker, warmer, cooler, etc.
Materials and Sources
Tempera paint and $18^{\prime \prime} \times 24^{\prime \prime}$ white construction paper

\author{
Painted papers, rubber \\ cement \\ Interaction of Color by Josef \\ Albers provides detailed \\ exercises of this type.
}


Procedures

Second Week

Day 1. Discuss 1 ife and work of Kandinsky.

Day 2. Using the landscape from Chapter II, students select a single typical quality to emphasize and make a collage, incorporating ideas of color changes

Day 3. Finish collages.

\section{Third Week}

Day 1. Take a sketching walk. Students draw the same scene from several positions, superimposing one over another, noticing negative as well as positive shapes.

Day 2. The students start a painting based on the drawings of the previous day, emphasizing warm and cool colors.

Day 3. Paint.

\section{Fourth Week}

Day 1. Look again at slides of Kandinsky's work. Analyze color relationships. Paint.

Day 2. Paint.
Materials and Sources

Slides: Bavarian Mountains with Village, Composition IV, Small Dream in Red

Painted papers, other colored papers, rubber cement, $18^{\prime \prime} \times 24^{\prime \prime}$ construction paper

Conté crayon on 18" $\mathrm{x} 24$ " bond drawing paper

Tempera paint on $18^{\prime \prime} \times 24^{\prime \prime}$ white construction paper

Slides: Bavarian Mountains with Village, Composition IV, Sma11 Dream in Red 
$\underline{\text { Procedures }}$

Day 3. Clean up, arrange an exhibition, discuss students' work from all three units.
Materials and Sources 


\section{CHAPTER V}

\section{SUMMARY}

In the course of covering the material presented in the second chapter of this thesis, the student should have gone through a process of gathering information about the natural world, considered ways of visual articulation of that information, primarily by means of light and dark values, enjoyed the investigations of fellow students, and shared the experience of a Renaissance artist who also used art as an investigative tool.

Chapter III focused on the student's personal response to the natural world. The formal emphasis included a consideration of hue variations and the emotionally expressive possibilities of those variations. The nineteenth century artist, Vincent van Gogh, was studied as an example of a painter whose 1 andscapes are permeated with personal feeling.

During the course of Chapter IV, the student should have had the opportunity to view the natural world as a source of abstract concepts, experimented with the relativity of color and its relationship to other design elements, and considered the life and work of the twentieth century artist, Wassily Kandinsky, who viewed his own concepts of the world as an ultimate reality. 
Thus, by the time the student has gone through the three proposed teaching units of this thesis, he should have participated in and visually articulated three major types of human experience: observing, feeling, and conceptualizing. An awareness that one genre, such as landscape painting, can become the vehicle for this variety of experience is one of the main teaching intentions of the thesis. Another hope is that the student will find points of contact between his own experience and work and that of the three artists here considered, and that in the process, the history of art may be felt as a vivid record of the experiences of other human beings. By the same token, as the formal aspects of art are integrated with the expressive purposes of each unit, it is hoped that these aspects will be meaningful and helpful to the student as he struggles to deal with his experience in a visual form. 


\section{FOOTNOTES}

${ }^{1}$ John Dewey, Art as Experience (New York: Milton, Balch and Company, $\overline{1934}$ ) p. 2-19 and Edmund Burke Feldman, Becoming Human Through Art (Englewood Cliffs, New Jersey:

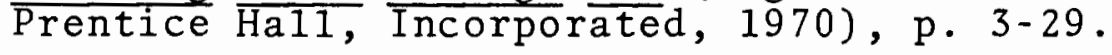

2 Kenneth Clark, Landscape Painting (New York: Charles Scribner's Sons, (1950) p. 1.

${ }^{3}$ A. Richard Turner, The Vision of Landscape in Renaissance Italy (Princeton, Ne $\overline{\text { J Jersey: }} \overline{\text { Princeton University }}$ $\overline{\operatorname{Press}}, \overline{1966)}$, p. 3 .

${ }^{4}$ Ibid., p. 7 .

${ }^{5}$ Wylie Sypher, Four Stages of Renaissance Style

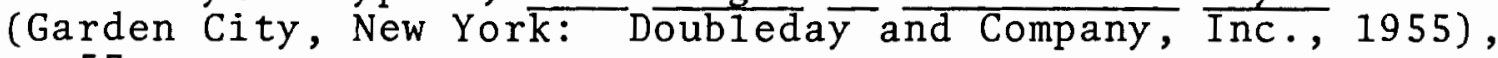
p. 57 .

${ }^{6} \mathrm{~J} . \mathrm{P}$. Richter, ed., The Literary Works of Leonardo da Vinci, 2 vols. (London: Phaidon Pubiishers, Inc., 1939),

${ }^{7}$ Walter Pater, The Renaissance (New York: Random House, 1919), p. 87 .

${ }^{8}$ Giorgio Vasari, The Lives of the Artists, trans. George Bull (Harmondsworth, Middlesex, England: Penguin Books Ltd., 1965) p. 255.

${ }^{9}$ Ibid., p. 257 .

10 Turner, p. 18.

${ }^{11}$ Richter, I, 6 .

${ }^{12}$ Viktor Lowenfeld and $w$. Lambert Brittain, Creative and Mental Growth (New York: The Macmillan Company, 1.947), p. $1 \overline{84}$. 
${ }^{13}$ Color terminology is that used by Faber Birren, History of Color in Painting (New York: Reinhold Publishing Corporation, 1965), p. $115 \mathrm{f}$.

14 This movie and all others cited in this thesis are available through the Multnomah County Intermediate Education District. Additional titles of interest might be:

Flower Structure and Function, Growth of Plants, Cousteau's Coral Jungle, and Wonders of the Desert.

${ }^{15}$ Rene Huyghe, Art and the Spirit of Man (New York:

Harry N. Abrams, Inc., 1962), p. $\frac{130 .}{430}$

${ }^{16}$ Marc Edo Tralbaut, Vincent van Gogh (New York: Viking Press, 1969), p. 29.

17 John Rewald, Post-Impressionism from van Gogh to Gaughin (New York: The Museum of Modern Art, $\frac{19}{2}$ ), p. 235 .

${ }^{18}$ Ernst Gombrich, The Story of Art (London and New York: Phaidon Publishers, Inc., 1950), p. 418.

${ }^{19}$ Tralbaut, p. $224 \mathrm{f}$.

20 Meyer Schapiro, Vincent van Gogh (New York: Harry N. Abrams, Inc., 1950), p. 21 .

${ }^{21}$ Ibid., p. 19.

22 Ibid., p. 24.

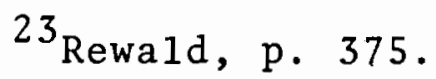

${ }^{24}$ Schapiro, p. 100.

${ }^{25}$ Erik H. Erickson, Identity Youth and Crises (New York: W.W. Norton and Company, Inc., 1968), p. 128 .

$26 \mathrm{John}$ Baur, Nature in Abstraction (New York: The MacMillam Company, 1958), p. 6.

${ }^{27}$ Will Grohmann, Wassily Kandinsky Life and Work (New York: Harry N. Abrams, 1958), p. 87. 
28 Wassily Kandinsky, Concerning the Spritual in Art (New York: George Wittenborn, 1947), p. $3 \frac{3}{3}$.

29 Grohmann, p. 33 .

30 Frank Whitford, Kandinsky (New York and London: Paul Hamlyn, 1967), p. 16 .

31 Grohmann, p. 89.

${ }^{32}$ Kandinsky, p. 20.

${ }^{33}$ Ibid., p. 58 .

${ }^{34}$ Grohmann, p. 188 .

${ }^{35}$ Feldman, p. 121. 


\section{SOURCES CONSULTED}

Albers, Josef. Interaction of Color. New Haven and London: Yale Unive rsity Press, 1971 .

Baur, John. Nature in Abstraction. New York: The MacMillan Company, 1958 .

Birren, Faber. History of Color in Painting. New York: Reinhold publishing Corporation, 1965.

Bovi, Arturo. Kandinsky. London, New York: Paul Hamlyn, 1970 .

Clark, Kenneth. Landscape Painting. New York: Charles Scribner's Sons, 1950 .

Clark, Kenneth. Leonardo da Vinci. Harmondsworth, Middlesex, England: Penguin Books Ltd., 1959.

Dewey, John. Art as Experience. New York: Milton, Balch and Company, $\frac{\text { I }}{19} \overline{34}$.

Eisenstaedt, Alfred. Witness to Nature. New York: The Viking press, 1971.

Erikson, Erik H. Identity Youth and Crisis. New York: W.W. Norton and Company, Inc., 1968 .

Feldman, Edmund Burke. Becoming Human Through Art. Englewood Cliffs, New Jersey: Prentic Hall, Inc., 1970.

Film Catalog. Portland, Oregon: Multnomah County Intermediate Education District, 1976.

Gombrich, Ernst. The Story of Art. London and New York: Phaidon Publishers Inc., $\overline{1950}$.

Grohman, Will. Wassily Kandinsky: Life and Work. New York: Harry N. Abrams, 1958 .

Hammacher, A.M. Genius and Disaster: The Ten Creative Years of Vincent van Gogh. New York: Harry. N. Abrams, 1969.

Hess, Thomas B. Abstract Painting. New York: The Viking Press, 1951 . 
Huyghe, René. Art and the Spirit of Man. New York: Harry N. Abrams, Inc., 1962 .

Itten, Johannes. The Art of Color. New York: Reinhold Publishing Corp., 1961.

Kandinsky, Wassily. Concerning the Spiritual in Art. New York: George wittenborn, Inc., 1947.

Keller, Horst. Vincent van Gogh: The Final Years. New York: Harry N. Abrams, 1969.

Kepes, Gyorgy. The New Landscape. Chicago: Paul Thesbald and Company, $1 \overline{956 .}$

Leonardo da Vinci Landscapes and Plants. Ed. Ludwig Goldscheider. London: Phaidon Publishers Inc., 1952.

Lowenfeld, Viktor and $w$. Lambert Brittain. Creative and Mental Growth. New York: The MacMillan Company, 1947.

Pater, Walter. The Renaissance. New York: Random House, 1919.

Rewald, John. Post Impressionism from van Gogh to Gaughin. New York: Museum of Modern Art, 1973 .

Richardson, John Adkins. Modern Art and Scientific Thought. Urbana: University of I11inois Press, 1971.

Richter, J.P., ed. The Literary Works of Leonardo da Vinci. 2 vols. London: Phaidon Pub. Inc., 1939.

Santini. Pier Carlo. Modern Landscape Painting. London: Phaidon Publishers Inc., 1972 .

Sausmarez, Maurice de. Basic Design: The Dymanics of Visual Form. New York: Reinhold Publishing Corpora-. tion, 1964 .

Schapiro, Meyer. Vincent van Gogh. New York: Harry N. Abrams, Inc., 1950 .

Sypher, Wylie. Four Stages of Renaissance Style. Garden City, New York: Doubleday and Company, Inc., 1955.

Tralbaut, Marc Edo. Vincent van Gogh. New York: Viking Press, 1969.

Turner, A. Richard. The Vision of Landscape in Renaissance Italy. Princeton, New Jersey: Princeton Univeristy Press, 1966. 
Vasari, Giorgio. The Lives of the Artists. Trans. George Bu11. Baltimore, Maryland: Penguin Books, 1965.

Vinci, Leonardo da. The Notebooks of Leonardo da Vinci. 2 vols. Ed. Jean paul Richter. New York: $\overline{\text { Dover }}$ Publications, Inc., 1970.

Whitford, Frank. Kandinsky. New York, London: Paul Hamlyn, 1967. 